\title{
Length-weight relationships and condition factor of the eaglebeak pacu Ossubtus xinguense Jégu, 1992 (Characiformes, Serrasalmidae), an endangered species from Rio Xingu rapids, northern Brazil
}

\author{
Andrade, MC. ${ }^{a, b *}$, Jesus, AJS. ${ }^{a, b}$ and Giarrizzo, T..$^{a, b, c}$ \\ ${ }^{a}$ Grupo de Ecologia Aquática, Laboratório de Biologia Pesqueira e Manejo dos Recursos Aquáticos, \\ Universidade Federal do Pará - UFPA, Cidade Universitária Prof. José Silveira Netto, \\ Avenida Perimetral, 2651, Terra Firme, CEP 66077-830, Belém, PA, Brazil \\ bPrograma de Pós-graduação em Ecologia Aquática e Pesca, Instituto de Ciências Biológicas, Universidade Federal do \\ Pará - UFPA, Cidade Universitária Prof. José Silveira Netto, Avenida Augusto Corrêa, 1, Guamá, \\ CEP 66075-110, Belém, PA, Brazil \\ 'Programa de Pós-graduação em Biodiversidade e Conservação, Faculdade de Ciências Biológicas, Universidade \\ Federal do Pará - UFPA, Avenida Cel. José Porfírio, 2515, São Sebastião, CEP 68372-010, Altamira, PA, Brazil \\ *e-mail: andrademarcosta@gmail.com
}

Received: May 19, 2014 - Accepted: September 6, 2014 - Distributed: August 31, 2015

(With 1 figure)

\begin{abstract}
This study reports on the length-weight relationships and condition factor for the endangered rheophilic fish Ossubtus xinguense Jégu from Rio Xingu rapids. This species is threatened by construction of the third largest hydroelectric in the world, the Belo Monte dam close to the city of Altamira, northern Brazil. Specimens were collected in the dry season between July 2012 and September 2012. Male specimens have body length larger than females, atypical in serrasalmid fishes, and different length-weight relationships were found between adult and juvenile specimens. This study presents the first biological characteristics for $O$. xinguense.
\end{abstract}

Keywords: conservation, hydroelectric impacts, growth stanzas, rheophilic fish, endemic species.

\section{Relações peso-comprimento e fator de condição do pacu-capivara Ossubtus xinguense Jégu, 1992 (Characiformes, Serrasalmidae), uma espécie ameaçada de extinção das corredeiras do Rio Xingu, norte do Brasil}

\section{Resumo}

Este estudo relata as relações peso-comprimento e fator de condição para o peixe reofílico ameaçado de extinção Ossubtus xinguense Jégu. Esta espécie, endêmica das corredeiras do Rio Xingu, é ameaçada pela construção da terceira maior hidrelétrica do mundo, denominada Belo Monte localizada às proximidades da cidade de Altamira, norte do Brasil. Os espécimes foram coletados na estação seca do rio, entre julho e setembro de 2012. Espécimes machos apresentaram tamanho corporal maior que fêmeas, condição atípica entre os peixes serrasalmídeos, e diferentes relações peso-comprimento foram encontradas entre espécimes juvenis e adultos. Este estudo apresenta as primeiras características biológicas para $O$. xinguense.

Palavras-chave: conservação, impactos por hidrelétricas, estrofes de crescimento, peixe reofílico, espécie endêmica.

\section{Introduction}

The Neotropical fish Ossubtus xinguense Jégu is a member of the Serrasalmidae family, which includes the famous piranhas (Jégu, 2003). Ossubtus xinguense, known as 'eaglebeak pacu' in the ornamental fish trade or as 'pacu-capivara' by local communities, is one of the rheophilic, endemic and rare fish from Rio Xingu. Due to its distribution restricted to rapids downstream of Altamira city, this species is seriously threatened by construction of the Belo Monte hydroelectric dam (Jégu and Zuanon, 2005).

The length-weight relationships (LWRs) and the condition factor $(\mathrm{K})$ of fish are an important tool for assessing the conservation status of a fish population. The LWR are used to estimate the weight corresponding to a given length, convert growth in length equations to growth in weight, and allow life history and morphological comparison between different fish species and/or populations (Froese, 2006; Giarrizzo et al., 2006; Joyeux et al., 2009). Furthermore, the condition factor in fish serves as an indicator of the physiological state of the fish in relation to its welfare (Le Cren, 1951). Most Serrasalmidae fish display distinct allometries in its morphological features throughout the ontogeny, in general, with highest growth 
rates for juveniles than adults (e.g. Géry, 1972; Jégu et al., 1989; 2002; Penna et al., 2005).

Given the importance of knowledge of the biology of endangered species, especially motivated by challenge to know the scientific value of biodiversity (Alho, 2008), this study aims to provide LWRs, $\mathrm{K}$ and growth stanzas of the $O$. xinguense for contributing with future ecological studies on this species, and somehow, to its conservation.

\section{Material and Methods}

The Xingu is a clear water river, a right-bank tributary of the lower Amazon basin. Field sampling was conducted downstream of the water capture channel for Belo Monte Dam (between $3^{\circ} 21^{\prime} 58^{\prime \prime} \mathrm{S} 51^{\circ} 59^{\prime} 37^{\prime \prime} \mathrm{W}$ and $3^{\circ} 21^{\prime} 57^{\prime \prime} \mathrm{S}$ $\left.51^{\circ} 43^{\prime} 59^{\prime \prime} \mathrm{W}\right)$, which will become the third largest hydroelectric dam in the world. During the low water period (between July 2012 and September 2012), O. xinguense were collected from random rapid sites by casting nets with different mesh sizes. The specimens were collected under permit number 057/2012 issued by the Brazilian Institute of Environment and Renewable Natural Resources (Instituto Brasileiro do Meio Ambiente e dos Recursos Naturais Renováveis - IBAMA) which has the specific constraints for capture and transport of $O$. xinguense. The fishes were measured with a digital caliper to the nearest $0.1 \mathrm{~cm}$ (standard length $=\mathrm{SL}$ ) and weighed with a digital balance to the nearest $0.01 \mathrm{~g}$ (total weight $=\mathrm{W}$ ). The data were grouped into size class according to Jégu (1992), classified as 'juveniles' when less than $10 \mathrm{~cm} \mathrm{SL}$, and as 'adults' when greater than $10 \mathrm{~cm}$ SL. The adults were further grouped according to sexual dimorphism evidenced by family (Andrade et al., 2013), where the specimens were classified as 'female' when having the anal-fin falcate and as 'male' when having a 2nd lobe on the anal fin.

The LWRs were calculated using the equation $\mathrm{W}=a \mathrm{SL}^{b}$ of Pauly (1984): $\log \mathrm{W}=\log a+b \log \mathrm{SL}$, where $a$ is a constant, and $b$ is the allometric coefficient. Possible outliers were removed by graphical inspection of log-log plot according to Froese (2006). The hypothetical values of isometry $(b=3)$ were checked using the Student's $t$-test at the level of $95 \%$ confidence limit (Sokal and Rohlf, 1987; Giarrizzo et al., 2011). Double logarithmic plotting was performed using ANCOVA to detect different growth stanzas (Froese, 2006) and growth dimorphism between LWRs. Differences in length and weight of the body between size class and sexes were tested using univariate PERMANOVA tests run on Euclidean distances matrices with 9999 permutations (Anderson, 2001). The condition factor $(\mathrm{K})$ was calculated as: $\mathrm{K}=\mathrm{W} / \mathrm{SL}^{3}$, and compared with Kruskal-Wallis using as factor the groups 'size class' and 'sexes' followed by the Dunn post hoc test.

\section{Results}

Overall, 149 specimens, grouped as 19 juveniles, 55 females and 75 males, of $O$. xinguense were analysed in the study. Differences between SL of females and males were found (PERMANOVA, Pseudo-F $=58.06, \mathrm{P}<0.0001$ ), with males being larger than females (mean $\mathrm{SL} \pm$ S.D., $18.64 \pm 1.74$, and $16.48 \pm 1.39$, respectively). Moreover, the new maximum length is found for a male $22.7 \mathrm{~cm} \mathrm{SL}$ (and $\mathrm{W}=495.24 \mathrm{~g}$ ). Despite the highest weight having been found for a female with $566.97 \mathrm{~g}$ (and $\mathrm{SL}=22.6 \mathrm{~cm}$ ), the males were heavier than females (mean $\mathrm{W} \pm$ S.D., $314.97 \pm 79.21$, and $224.75 \pm 48.83$, respectively), (PERMANOVA, Pseudo-F $=55.73, \mathrm{P}<0.0001$ ).

Length-weight relationships by individual group were significant $(\mathrm{P}<0.05)$. Parameters of the LWRs for O. xinguense are shown in Table 1. Females and males showed negative allometry ( $b=2.829, b=2.637$, respectively), and no significant difference in growth dimorphism was detected by inspection of the double logarithmic plot (ANCOVA, d.f. $=1, P>0.05$ ). Therefore, female and male individuals were pooled and a new LWR was estimated for the adult population. On the other hand, a double logarithmic plot between juveniles and adults found two growth stanzas (ANCOVA, d.f. $=1, \mathrm{P}<0.001$, Figure 1).

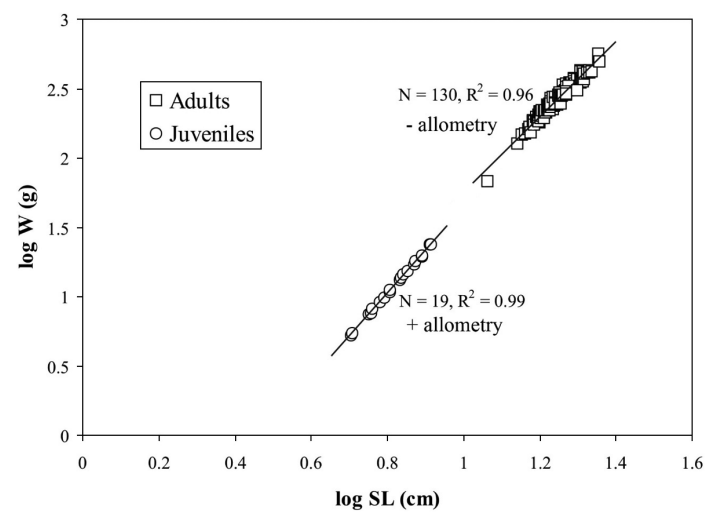

Figure 1. Double logarithmic plot for two growth stanzas of Ossubtus xinguense caught between July and September 2012 in the Volta Grande region, Rio Xingu. SL: standard length; W: total weight; $\mathrm{N}$ : sample size; $\mathrm{R}^{2}$ : Pearson $r$-squared.

Table 1. Length-weight relationships and statistical parameters of specimens of Ossubtus xinguense caught between July and September 2012 at the Volta Grande region, Rio Xingu. N: sample size; SL: standard length; W: total weight; LWR: length-weight relationships; $\mathrm{R}^{2}$ : Pearson $r$-squared; 95\% CI of $a$ : confidence intervals of $a$; and 95\% CI of $b$ : confidence intervals of $b$.

\begin{tabular}{cccccccc}
\hline Group & $\mathbf{N}$ & \multicolumn{1}{c}{ SL (cm) } & \multicolumn{1}{c}{$\mathbf{W}(\mathbf{g})$} & \multicolumn{1}{c}{ LWR } & $\mathbf{R}^{\mathbf{2}}$ & $\mathbf{9 5 \%} \mathbf{C I} \boldsymbol{a}$ & $\mathbf{9 5 \%} \mathbf{C I} \boldsymbol{b}$ \\
\hline Juveniles & 19 & $5.06-8.18$ & $5.23-25.23$ & $\mathrm{~W}=0.034 \times \mathrm{SL}^{3.117}$ & 0.99 & $0.027-0.043$ & $2.986-3.247$ \\
Adults & 130 & $11.52-22.70$ & $68.51-566.97$ & $\mathrm{~W}=0.109 \times \mathrm{SL}^{2.726}$ & 0.96 & $0.082-0.146$ & $2.616-2.816$ \\
\hline
\end{tabular}


The analysis of $\mathrm{K}$ detected significant differences among all factors, size class and sex (Kruskal-Wallis, $\mathrm{P}<0.001$ ). The biggest difference was found between size class $(\mathrm{P}<0.001)$, where adults fishes had a significantly higher mean $\mathrm{K}$ value than juveniles (mean $\mathrm{K} \pm$ S.E. $4.85 \pm 0.03$ and $4.26 \pm 0.07$, respectively; $\mathrm{P}<0.001$ ). Although the $\mathrm{K}$ values between females and males were closest, they were significantly different, in that females had a $\mathrm{K}$ value slightly higher than males' $\mathrm{K}$ value $(4.95 \pm 0.04$ and $4.78 \pm 0.04$, respectively; $\mathrm{P}<0.05$ ).

\section{Discussion}

Ossubtus xinguense is among the most endangered species from Rio Xingu basin, northern Brazil. This species, as well as Hypancistrus zebra Isbrücker \& Nijssen, 1991, is listed in the Red List of Threatened Brazilian Fauna (Rosa and Lima, 2008) due to being endemic to the Volta Grande region, lower Xingu basin. Not only the endemism factor, but its strictly rheophilic nature and exclusive habitat of rocky rapids associated with rupestral seedlings of Podostemaceae make $O$. xinguense vulnerable to the loss of lotic systems. The species is therefore greatly threatened by the construction of hydroelectric dams. One of the main suggestions as a conservation strategy for the species is to conduct studies about biological characteristics of the species in its natural environment. After more than two decades of formal description of the $O$. xinguense little known about it. Jégu and Zuanon (2005) believe the species to be rare, but in this study performed in just three months a considerable number of individuals $(\mathrm{N}=149)$ of the species were captured in the Volta Grande region. However, this region is doomed to have a drastically changed landscape after the conclusion of the construction of Belo Monte hydroelectric dam.

Most Serrasalmidae species display size dimorphism in which the females are larger than males. This pattern can be illustrated as much by large herbivores such as Colossoma macropomum (Cuvier, 1816) from lowland rivers (Loubens and Panfili, 1997; Villacorta-Correa and Saint-Paul, 1999), as by carnivores Pygocentrus nattereri Kner, 1858 from highland areas (Duponchelle et al., 2007). Although $O$. xinguense displays size dimorphism, it does not follow this pattern. Ordinarily the mature males are larger in body size, but weigh less than mature females as showed herein. However, the LWR between sexes do not differ, and, in relation to growth type, both sexes have a negative allometric growth. In relation to growth stanzas between size class, $O$. xinguense presents a growth type which apparently follows the morphological pattern adopted by Jégu (1992), juveniles (up to $10 \mathrm{~cm} \mathrm{SL}$ ) have positive allometric growth $(b=3.117)$, while the adults have negative allometric growth $(b=2.716)$. Nevertheless, the LWR provided to juveniles, although significant ( $t$-test, $\mathrm{P}<0.05)$ and with high correlation $\left(\mathrm{R}^{2}=0.99\right)$, should be observed with caution due to the low sample size $(\mathrm{N}=19)$, far from the minimum of 100 specimens recommended by Froese et al. (2011). Taking into account the condition factor $(\mathrm{K})$, the females of $O$. xinguense display $\mathrm{K}$ value higher than males. This result was expected, considering that females are smaller and heavier. Given that the $\mathrm{K}$ is used to compare the welfare of fishes, which is equivalent to fatness, it is expected that the $\mathrm{K}$ value of juveniles is lower than that of adults. This indicates better conditions in adults for activities that require higher energy costs such as reproduction.

We suppose that these differences may be related to an ontogenetic change in feeding behaviour of this species, similar to that displayed by other serrasalmid species, Mylesinus paraschomburgkii Jégu, Santos \& Ferreira, 1989. Mylesinus paraschomburgkii in which juveniles feed basically on aquatic invertebrates, and on becoming adults, begin feeding on aquatic plants (Jégu et al., 1989). Therefore, the abrupt change of growth type between juveniles and adults (stanzas) should be re-examined with an increase in juvenile specimens. This study represents the first contribution to the biology of the eaglebeak pacu, an endangered species, and will serve as support for future ecological studies of the species.

\section{Acknowledgements}

The authors are grateful to IBAMA for issuing a collection permit. They are also grateful to 'LEME Engenharia' and 'NORTE Energia' for allowing publication of the data used in this study. MCA and AJSJ were funded by the Coordenação de Aperfeiçoamento de Pessoal de Nível Superior (CAPES), and TG receives a productivity grant from CNPq (process: 308278/2012-7). The authors belong to the IctioXingu CNPq Research Group.

\section{References}

ALHO, CJR., 2008. The value of biodiversity. Brazilian Journal of Biology, vol. 68, no. 4, supplement, p. 1115-1118. http://dx.doi. org/10.1590/S1519-69842008000500018. PMid:19197481.

ANDERSON, MJ., 2001. Permutation tests for univariate or multivariate analysis of variance and regression. Canadian Journal of Fisheries and Aquatic Sciences, vol. 58, no. 3, p. 626-639. http://dx.doi.org/10.1139/f01-004.

ANDRADE, MC., GIARRIZZO, T. and JÉGU, M., 2013. Tometes camunani (Characiformes: Serrasalmidae), a new species of phytophagous fish from the Guiana Shield, rio Trombetas basin, Brazil. Neotropical Ichthyology, vol. 11, no. 2, p. 297-306. http:// dx.doi.org/10.1590/S1679-62252013000200008.

DUPONCHELlE, F., LINO, F., HUBERT, N., PANFILI, J., RENNO, JF., BARAS, E., TORRICO, JP., DUGUE, R. and NUÑEZ, J., 2007. Environment-related life history trait variations of the red-bellied piranha, Pygocentrus nattereri, in two river basins of the Bolivian Amazon. Journal of Fish Biology, vol. 71, no. 4, p. 1113-1134. http://dx.doi.org/10.1111/j.1095-8649.2007.01583.x.

FROESE, R., 2006. Cube law, condition factor and weight-length relationships: history, meta-analysis and recommendations. Journal of Applied Ichthyology, vol. 22, no. 4, p. 241-253. http://dx.doi. org/10.1111/j.1439-0426.2006.00805.x. 
FROESE, R., TSIKLIRAS, AC. and STERGIOU, KI., 2011. Editorial note on weight-length relations of fishes. Acta Ichthyologica et Piscatoria, vol. 41, no. 4, p. 261-263. http://dx.doi.org/10.3750/ AIP2011.41.4.01.

GÉRY, J., 1972. Poissons characoïdes des Guyanes. I. Généralités. II. Famille des Serrasalmidae. Zoologische Verhandelingen, no. 122, p. $1-250$.

GIARRIZZO, T., BASTOS, D. and ANDRADE, M., 2011. Lengthweight relationships for selected fish species of Rio Trombetas Biological Reserve: a reference study for the Amazonian basin. Journal of Applied Ichthyology, vol. 27, no. 6, p. 1422-1424. http://dx.doi.org/10.1111/j.1439-0426.2011.01820.x.

GIARRIZZO, T., JESUS, AJS., LAMEIRA, EC., ALMEIDA, JBA., ISSAC, V. and SAINT-PAUL, U., 2006. Weight-length relationships for intertidal fish fauna in a mangrove estuary in Northern Brazil. Journal of Applied Ichthyology, vol. 22, no. 4, p. 325-327. http://dx.doi.org/10.1111/j.1439-0426.2006.00671.x.

JÉGU, M. and ZUANON, J., 2005. Threatened fishes of the world: Ossubtus xinguense (Jégu 1992) (Characidae: Serrasalminae). Environmental Biology of Fishes, vol. 73, no. 4, p. 414-414. http://dx.doi.org/10.1007/s10641-004-4230-5.

JÉGU, M., 1992. Ossubtus xinguense, nouveaux genre et espèce du Rio Xingu, Amazonie, Brésil (Teleostei: Serrasalminae). Ichthyological Exploration of Freshwaters, vol. 3, p. 235-252.

JÉGU, M., 2003. Subfamily Serrasalminae (pacus and piranhas). In REIS, RE., KULLANDER, SO. and FERRARIS JUNIOR, CJ. (Eds.). Check list of freshwater fishes of South and Central America. Porto Alegre: Edipucrs. p. 182-196.

JÉGU, M., KEITH, P. and BELMONT-JÉGU, E., 2002. Une nouvelle espèce de Tometes (Teleostei: Characidae: Serrasalminae) du bouclier guyanais, Tometes lebaili n. sp. Bulletin Francais de la Peche et de la Pisciculture, no. 364, p. 23-48. http://dx.doi. org/10.1051/kmae:2002002.

JÉGU, M., SANTOS, GM. and FERREIRA, EJG., 1989. Une nouvelle espèce du genre Mylesinus (Pisces, Serrasalmidae), M. paraschomburgkii, décrite des bassins du Trombetas et du
Uatumã (Brésil, Amazonie). Revue d'Hydrobiologie Tropicale, vol. 22 , p. 49-62.

JOYEUX, J-C., GIARRIZZO, T., MACIEIRA, RM., SPACH, HL. and VASKE, T Jr., 2009. Length-weight relationships for Brazilian estuarine fishes along a latitudinal gradient. Journal of Applied Ichthyology, vol. 25, no. 3, p. 350-355. http://dx.doi. org/10.1111/j.1439-0426.2008.01062.x.

LE-CREN, ED., 1951. The lengh-weight relationship and seasonal cycle in gonadal weight and condition in the perch, Perca fluviatilus. Journal of Animal Ecology, vol. 20, no. 2, p. 201-219. http://dx.doi.org/10.2307/1540.

LOUBENS, G. and PANFILI, J., 1997. Biologie de Colossoma macropomum (Teleostei: Serrasalmidae) dans le bassin du Mamoré (Amazonie bolivienne). Ichthyological Exploration of Freshwaters, vol. 8, p. 1-22.

PAULY, D., 1984. Fish population dynamics in tropical waters: a manual for use with programmable calculators. Studies and Reviews, vol. 8, p. 325.

PENNA, MAH., VILLACORTA-CORREAA, MA., WALTER, T. and PETRERE-JR, M., 2005. Growth of the tambaqui Colossoma macropomum (Cuvier) (Characiformes: Characidae): which is the best model? Brazilian Journal of Biology, vol. 65, no. 1, p. 129-139. http://dx.doi.org/10.1590/S1519-69842005000100017. PMid:16025912.

ROSA, RS. and LIMA, FCT., 2008. Os peixes brasileiros ameaçados de extinção. In MACHADO, ABM., DRUMMOND, GM. and PAGLIA, AP. (Eds.). Livro vermelho da fauna brasileira ameaçada de extinção. Brasília: MMA. p. 9-285.

SOKAL, RR. and ROHLF, FJ., 1987. Introduction to biostatistics. 2nd ed. New York: Freeman Publications. 363 p.

VILLACORTA-CORREA, MA. and SAINT-PAUL, U., 1999. Structural indexes and sexual maturity of tambaqui Colossoma macropomum (Cuvier, 1818) (Characiformes: Characidae) in central Amazon, Brazil. Revista Brasileira de Biologia = Brazilian Journal of Biology, vol. 59, no. 4, p. 637-652. http:// dx.doi.org/10.1590/S0034-71081999000400013. PMid:23505652. 